GANDRUNG: Jurnal Pengabdian Kepada Masyarakat ISSN: 2721-6136 (Online)

\title{
Accompaniment of Village Library Development in Grajagan Village, Purwoharjo District, Banyuwangi Regency
}

\author{
Hari Siswoyo" ${ }^{*}$, Dwi Priyantoro², M. Taufiq ${ }^{3}$, Andre P. Hendrawan, Eri Widayanti ${ }^{5}$ \\ 1,2,3,4,5Department of Water Resources Engineering, Faculty of Engineering, Brawijaya University \\ *Email : hari_siswoyo@ub.ac.id

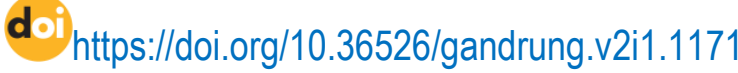

\begin{abstract}
The Grajagan village had a library located at the village office. So far, the library has not been managed and utilized optimally. The problems that occur in this library include the lack of book collections, the absence of chairs and tables for readers, the condition of the library is not well organized, and the library staff were not trained in managing the library. These problems have resulted in the low interest of the people of Grajagan village to visit the village library. To solve the problems, it was necessary to provide assistance in library development. Library development is carried out through the addition of book collections, providing chairs and tables for readers, arranging library space, and training for library staff. Based on the results of community service activities that have been carried out, it can be stated that the library's book collection has increased by 88 books, the library space becomes more comfortable with the increase in furniture, and the library staff has increased their knowledge in terms of library management. To further increase the role and function of the library, promotion or introduction to the library's book collections and facilities to local villagers is required.
\end{abstract}

Keywords:Books Collection, Grajagan Village, Transfer of Knowledge, Village Library

\section{Pendahuluan}

Desa Grajagan berada di wilayah Kecamatan Purwoharjo, Kabupaten Banyuwangi, Provinsi Jawa Timur dengan luas wilayah 73,19 km² (BPS Kabupaten Banyuwangi, 2019). Desa Grajagan terdiri atas 5 dusun, 22 RW, dan 117 RT. Jumlah penduduk Desa Grajagan sebanyak 14.180 jiwa yang terdiri atas 7.123 laki-laki dan 7.057 perempuan. Tingkat kepadatan penduduk di Desa Grajagan adalah 1.636 jiwa $/ \mathrm{km}^{2}$. Pekerjaan utama penduduk Desa Grajagan berdasarkan bidangnya antara lain meliputi: bidang pertanian, kehutanan, perkebunan, dan perikanan sebanyak 3.601 orang, bidang pertambangan dan penggalian sebanyak 11 orang, bidang industri pengolahan sebanyak 187 orang, bidang listrik, air, dan gas sebanyak 9 orang, bidang bangunan sebanyak 96 orang, bidang perdagangan, rumah makan, dan hotel sebanyak 1.448 orang, bidang angkutan, pergudangan, dan komunikasi sebanyak 173 orang, bidang keuangan sebanyak 84 orang, dan bidang jasa kemasyarakatan sosial sebanyak 947 orang (BPS Kabupaten Banyuwangi, 2018).

Sarana kesehatan yang terdapat di Desa Grajagan antara lain 1 Puskesmas, 1 Puskesmas Pembantu, 1 Balai Kesehatan, 4 Poliklinik Desa (Polindes), dan 15 Posyandu. Sarana pendidikan (sekolah) yang terdapat di Desa Grajagan meliputi 5 Taman Kanak-kanak (TK), 7 Sekolah Dasar (SD), 
GANDRUNG: Jurnal Pengabdian Kepada Masyarakat ISSN: 2721-6136 (Online)

2 Madrasah Ibtidaiyah (MI), dan 2 Sekolah Menengah Pertama (SMP) (BPS Kabupaten Banyuwangi, 2019). Selain institusi-institusi pendidikan formal tersebut, Desa Grajagan juga memiliki Perpustakaan Desa sebagai sarana sumber belajar bagi warga desa setempat. Perpustakaan Desa tersebut berada di dalam lingkungan Kantor Desa Grajagan.

Perpustakaan Desa merupakan salah satu jenis perpustakaan umum yang berkedudukan di suatu desa atau kelurahan.Perpustakaan desa merupakan sarana belajarmasyarakat dimana idealnya tersedia berbagai sumberinformasi sebagai sumber belajarmasyarakat, sehingga sumber-sumber informasiyang merupakan koleksi perpustakaan desa harus meliputiberbagai subjek pengetahuan (Rodiah et al., 2018). Perpustakaan merupakan salah satu sumber belajar, dimana menurut Undang-Undang Republik Indonesia No. 43, tahun 2007 tentang Perpustakaan,perpustakaan harus memenuhi standar nasional yang terdiri atas koleksi perpustakaan, sarana dan prasarana, pelayanan perpustakaan, penyelenggaraan, dan pengelolaan. Namun demikian, kondisi idial sesuai dengan standar tersebut tidak selalu terdapat pada setiap perpustakaan.

Perpustakaan Desa Grajagan masih belum terkelola dan termanfaatkan secara optimal. Permasalahan yang terjadi di Perpustakaan Desa Grajagan antara lain minimnya koleksi buku, belum adanya fasilitas kursi dan meja bagi pembaca, kondisi perpustakaan belum tertata dengan baik, dan belum terlatihnya petugas perpustakaan dalam mengelola perpustakaan (Hasil observasi di lapangan dan wawancara dengan aparat Desa Grajagan, 5 September 2019). Pemasalahan-permasalahan tersebut berdampak terhadap rendahnya minat masyarakat Desa Grajagan untuk mengunjungi perpustakaan desa.

Untuk mengatasi permasalahan yang terdapat di Perpustakaan Desa Grajagan perlu dilakukan pendampingan pengembangan perpustakaan. Konsep perubahan harus disesuaikan dengan kebutuhan pengguna sehingga dapat terbentuk perpustakaan yang ideal bagi masyarakat (Widiyastuti, 2017). Pengembangan perpustakaan dapat dilakukan melalui penambahan koleksi buku, pemberian fasilitas kursi dan meja bagi pembaca, penataan ruang perpustakaan, dan pelatihan bagi petugas perpustakaan. Dengan adanya kegiatan ini, diharapkan akan tercipta kondisi perpustakaan yang ideal (Darmono, 2017) setidaknya mencakup hal-hal sebagai berikut: tempat baca yang memadai, perabot yang memadai, koleksi buku yang lebih lengkap dan sesuai kebutuhan masyarakat, dengan pelayanan yang menyenangkan dari petugas perpustakaan.Tujuan dilakukannya kegiatan pengabdian kepadamasyarakat ini adalah untuk menambah koleksi buku di Perpustakaan Desa Grajagan, menata koleksi buku dan menambah perabot di Perpustakaan Desa Grajagan, dan memberikan alih pengetahuan tentang perpustakaan kepada petugas Perpustakaan Desa Grajagandalam hal pengelolaan perpustakaan. 
GANDRUNG: Jurnal Pengabdian Kepada Masyarakat ISSN: 2721-6136 (Online)

\section{Metode}

Kegiatan pengabdian kepada masyarakat ini secara keseluruhan dilaksanakan dalam kurun waktu 4 bulan yaitu antara bulan April 2020 sampai dengan bulan Agustus 2020, yang secara garis besar meliputi kegiatan persiapan, koordinasi baik secara internal maupun eksternal, pengadaan buku dan perabot perpustakaan, pendampingan di lokasi mitra (Desa Grajagan), sampai dengan penyusunan laporan hasil kegiatan.Kegiatan pendampingan di lokasi mitra dilakukan pada bulan Agustus 2020, mengingat kegiatan dilakukan pada saat terjadi pandemi maka pelaksanaan kegiatan dilakukan secara terbatas (waktu dan materi dipadatkan) tanpa mengurangi esensi dari kegiatan tersebut, dengan tetap mematuhi protokol kesehatan. Kegiatan yang dilakukan dalam rangka memberikan pendampingan pengembangan perpustakaan desa di Desa Grajagan meliputi :

1. Penambahan koleksi buku

Penambahan koleksi buku dilakukan dengan tujuan untuk meningkatkan minat masyarakat untuk mengunjungi dan membaca buku di perpustakaan. Koleksi bahan perpustakaan yang baik dapat memenuhi selera, keinginan, dan kebutuhan pemustaka (Sriagustini, 2016). Penambahan koleksi buku dilakukan melalui pembelian buku-buku untuk koleksi perpustakaan Desa Grajagan. Buku-buku yang ditambahkan terutama yang terkait dengan bidang-bidang pekerjaan/profesi warga di desa setempat (seperti petani, nelayan, perbengkelan, kesehatan, kuliner, dan keterampilan) dan buku-buku pengetahuan umum. Selain itu, perlu ditambahkan koleksi buku cerita anak dan buku ilmiah populer untuk anak (Restanti et al., 2017).

2. Penataan perpustakaan

Penataan perpustakaan dilakukan dalam kaitannya perencanaan bagian dalam perpustakaan yang mempunyai tujuan sesuai dengan fungsinya dan memiliki unsur keindahan serta mampu memberi rasa nyaman bagi penggunanya (Widiyastuti, 2017), diantaranya seperti kenyamanan ruang untuk membaca, penataan susunan rak untuk koleksi bahan pustaka, dan fasilitas pendukung lainnya.

3. Alih pengetahuan kepada petugas perpustakaan desa

Kegiatan ini dilakukan dengan memberikan alih pengetahuan dari petugas ruang baca Jurusan Teknik Pengairan Fakultas Teknik Universitas Brawijaya kepada petugas perpustakaan Desa Grajagan. Materi yang diberikan secara langsung dalam alih pengetahuan tentang pengelolaan perpustakaan yang meliputi (Restanti et al., 2017): pengembangan koleksi, pengelolaan bahan pustaka, dan pelayanan perpustakaan.

4. Pemberian umpan balik dari mitra

Untukmengetahui respon mitra kegiatan terkait hasil kegiatan pengabdian kepada masyarakat Volume 2, Number 1, Februari 2021| 169 Accompaniment of Village Library Developmentin Grajagan Village, Purwoharjo District, Banyuwangi Regency 
yang telah dilakukan, pada akhir kegiatan dilakukan pemberian umpan balik dari mitra kegiatan kepada pelaksana kegiatan. Pemberian umpan balik dilakukan melalui pengisian angket yang disusun oleh tim pelaksana kegiatan dan diisi oleh mitra kegiatan. Angket disusun dengan pilihan jawaban dalam skala sikap menggunakan Skala Likert (Riduwan, 2010).

\section{Hasil dan Diskusi}

Kegiatan pengabdian kepada masyarakat ini dilakukan di Perpustakaan Desa Grajagan yang berada di Kantor Desa Grajagan. Dengan memberlakukan protokol kesehatan, yaitu mencuci tangan, mengenakan masker, dan menjaga jarak, tim pelaksana kegiatan diterima langsung oleh Kepala Desa Grajagan dan para aparat desa dalam jumlah terbatas. Kegiatan diawali dengan diskusi antara ketua pelaksana kegiatan pengabdian kepada masyarakat dengan kepala desa yang didampingi beberapa aparat desa di ruang kerja kepala desa seperti ditunjukkan dalam Gambar 1.

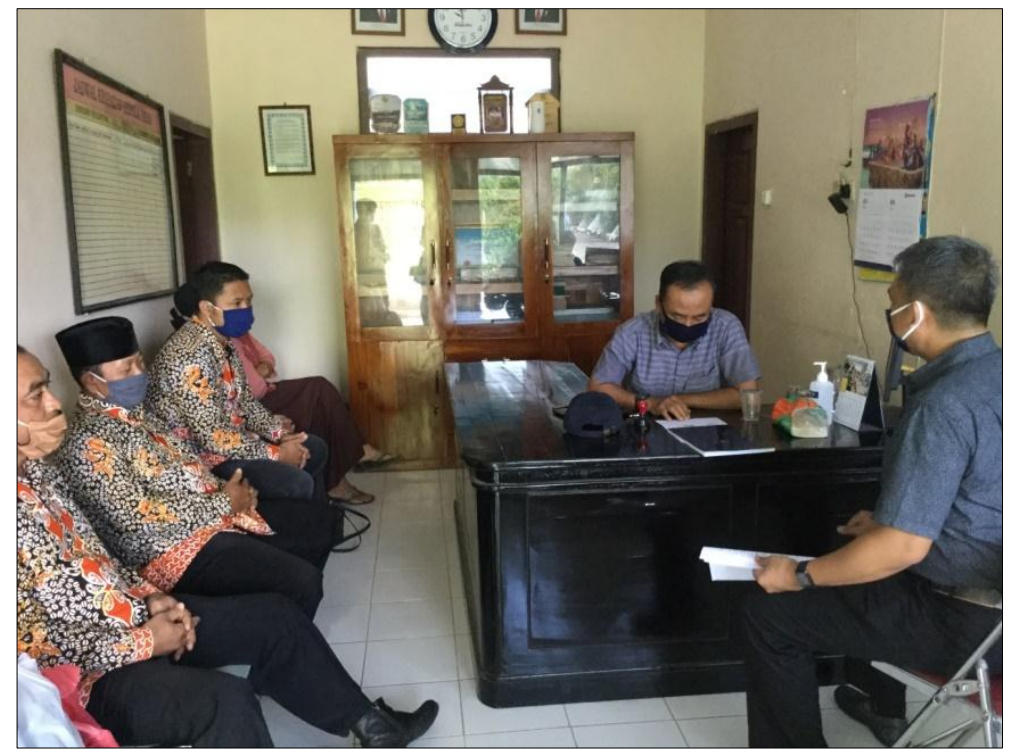

Gambar1. Diskusi antara ketua pelaksana kegiatan dengan Kepala Desa Grajagan

Penyerahan bantuan pengadaan koleksi buku untuk Perpustakaan Desa Grajagan dilakukan di ruang perpustakaan tersebut. Serah terima dilakukan secara langsung oleh ketua tim pelaksana kegiatan pengabdian masyarakat kepada Kepala Desa Grajagan. Buku yang diserahkan sejumlah 88 judul buku, yang terdiri atas 9 buku tentang pertanian, 8 buku tentang peternakan, 6 buku tentang perikanan, 7 buku tentang perbengkelan, 19 buku tentang pengetahuan umum, 9 buku tentang kuliner, 6 buku tentang keterampilan, 8 buku tentang kesehatan, 9 buku tentang cerita anak, dan 7 buku ilmiah populer anak. Buku-buku yang diserahkan tersebut semuanya merupakan buku baru. Buku-buku yang diserahkan tersebut diterima dengan baik oleh Kepala Desa Grajagan untuk selanjutnya buku-buku tersebut menjadi 
GANDRUNG: Jurnal Pengabdian Kepada Masyarakat ISSN: 2721-6136 (Online)

aset atau inventaris milik Desa Grajagan khususnya Perpustakaan Desa Grajagan. Dokumentasi serah terima bantuan koleksi buku seperti ditunjukkan dalam Gambar 2.

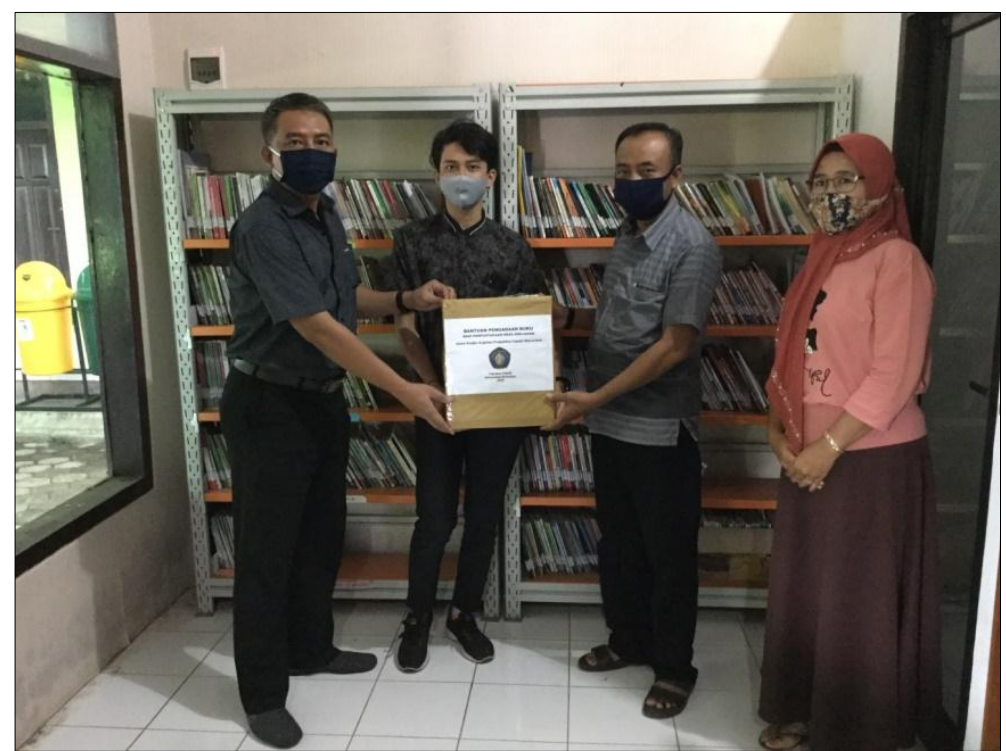

Gambar 2. Penyerahan bantuan koleksi buku untuk Perpustakaan Desa Grajagan

Penataan perpustakaan yang dilakukan oleh tim pelaksana kegiatan meliputi penataan koleksi buku dan penambahan perabot untuk perpustakaan. Tim pelaksana kegiatan memberikan arahan tentang tata cara penataan koleksi buku di perpustakaan. Dokumentasi kegiatan pemberian arahan penataan koleksi buku seperti ditunjukkan dalam Gambar 3.

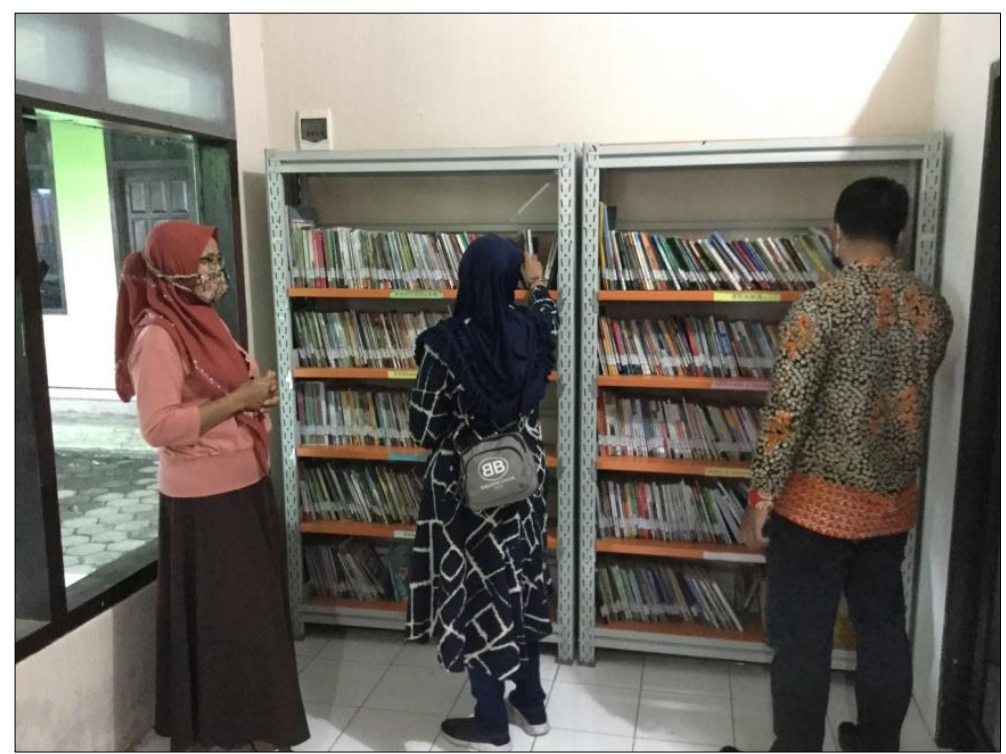

Gambar 3. Penataan koleksi buku

Bantuan pengadaan perabot dan perlengkapan perpustakaan yang diberikan untuk meningkatkan kenyamanan bagi pembaca maupun petugas perpustakaan desa. Bantuan berupa perabot dan Volume 2, Number 1, Februari 2021| 171 Accompaniment of Village Library Developmentin Grajagan Village, Purwoharjo District, Banyuwangi Regency 
GANDRUNG: Jurnal Pengabdian Kepada Masyarakat ISSN: 2721-6136 (Online)

perlengkapan perpustakaan yang diberikan meliputi 1 unit meja untuk membaca, 2 unit kursi untuk tempat duduk pembaca, rak untuk penitipan tas/barang, jam dinding, taplak meja, dan seperangkat alat tulis kantor. Dokumentasi bantuan pengadaan perabot perpustakaan yang diberikan oleh tim pelaksana kegiatan ditunjukkan dalam Gambar 4.

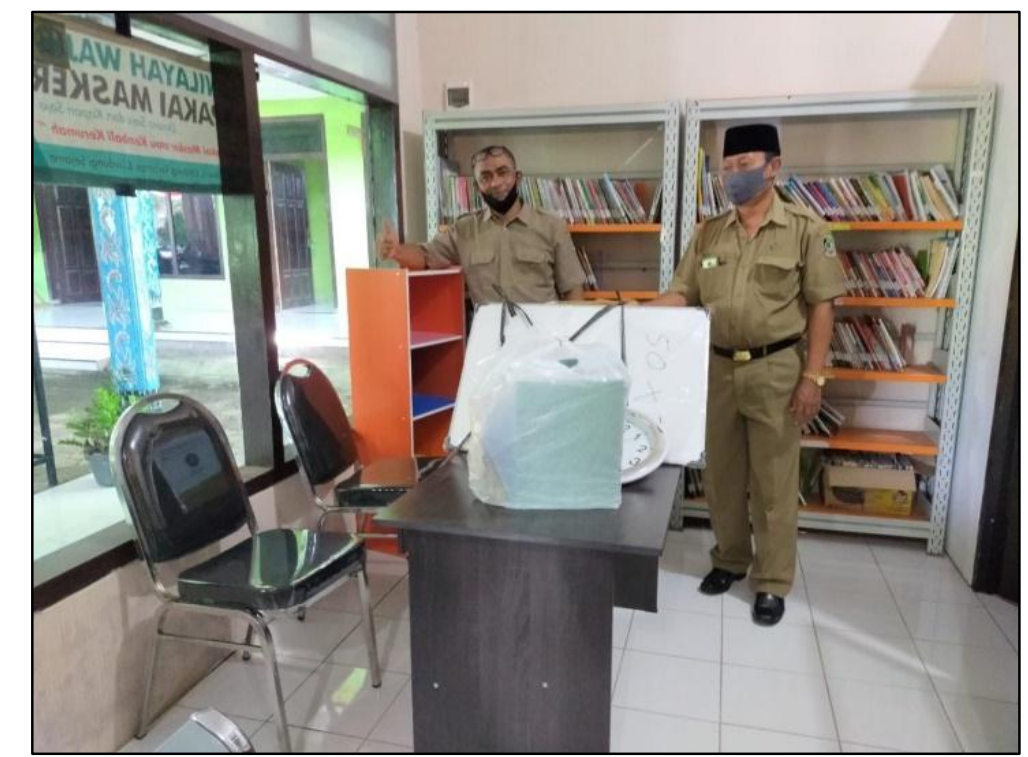

Gambar 4. Bantuan pengadaan perabot dan perlengkapan perpustakaan

Alih pengetahuan oleh tim pelaksana kegiatan kepada petugas Perpustakaan Desa Grajagan dilakukan berdasarkan indentifikasi permasalahan dalam pengelolaan perpustakaan tersebut. Berdasarkan kondisi yang ada, sirkulasi Perpustakaan Desa Grajagan dilakukan melalui pencatatan di buku, tidak ada kartu peminjaman, dan kartu yang ada di kantong buku belum terisi. Dengan demikian, perlu disampaikan pengetahuan tentang fungsi dan kegunaan kartu yang ada di belakang buku, cara pengisian, dan kegunaanya. Buku yang menjadi koleksi di Perpustakaan Desa Grajagan berasal dari sumbangan pemerintah Provinsi Jawa Timur yang sudah lengkap sesuai standar perpustakaan. Namun demikian, dalam pelaksanaannya fungsi dan kegunaan kelengkapan yang ada di buku belum terimplementasikan, sehingga perlu adanya informasi fungsi dan kegunaan tersebut.Alih pengetahuan dalam kegiatan ini difokuskan terhadap pengklasifikasian dan pengkodean buku. Alih pengetahuan sebagai dasar pengelolaan perpustakaan yang diberikan meliputi materi: penentuan subyek buku (Miswan, 2003), e-Dewey Decimal Classification (Rotmianto, 2015), pembuatan label punggung buku, kartu buku, dan sirkulasi perpustakaan (Badan Arsip dan Perpustakaan Pemerintah Provinsi Jawa Tengah, 2009).

Di akhir kegiatan, tim pelaksana kegiatan pengabdian kepada masyarakat memberikan umpan balik kepada mitra kegiatan dengan cara membagikan angket. Upaya ini dilakukan guna mengetahui respon dari mitra terkait hasil kegiatan pengabdian kepada masyarakat yang telah dilakukan. Angket 
GANDRUNG: Jurnal Pengabdian Kepada Masyarakat ISSN: 2721-6136 (Online)

dibuat secara sederhana dengan 4 butir pertanyaan yang secara langsung terkait dengan kegiatan pengabdian kepada masyarakat yang dilakukan, agar kuisioner tersebut dapat dengan mudah dipahami dan dijawab oleh mitra. Pertanyaan dilengkapi dengan pilihan jawaban dalam skala sikap menggunakan Skala Likert (Riduwan, 2010). Butir-butir pertanyaan yang diajukanmeliputi: (1) Apakah kegiatan yang dilakukan dibutuhkan di Desa Grajagan?, (2) Apakah kegiatan yang dilakukan memberikan tambahan pengetahuan bagi aparat dan warga Desa Grajagan?, (3) Apakah kegiatan yang dilakukan memberikan sumbangsih bagi pembangunan yang dilakukan di Desa Grajagan?, dan (4) Apakah kegiatan pengabdian kepada masyarakat yang dilakukan oleh Tim dari Universitas Brawijaya masih diharapkan berlangsung lagi di tahun berikutnya?.

Angket diisi oleh responden dalam jumlah terbatas ( 6 orang) yaitu kepala desa beserta para aparat desa yang hadir pada saat kegiatan. Seluruh responden menyatakan bahwa kegiatan yang dilakukan sangat dibutuhkan di Desa Grajagan.Seluruh responden menyatakan bahwa kegiatan yang dilakukan sangat memberi tambahan pengetahuan bagi aparat dan warga Desa Grajagan.Seluruh responden menyatakan bahwa kegiatan yang dilakukan sangat memberi sumbangsih bagi pembangunan yang dilakukan di Desa Grajagan. Seluruh responden menyatakan bahwa kegiatan pengabdian kepada masyarakat yang dilakukan oleh Tim dari Universitas Brawijaya sangat diharapkan berlangsung lagidi tahun berikutnya. Secara umum mitra kegiatan memiliki respon positif dan puas dengan kegiatan pengabdian kepada masyarakat yang telah dilakukan oleh tim pelaksana kegiatan.

Kegiatan pendampingan pengembangan perpustakaan desa di Desa Grajagan yang dilakukan memberikan dampak positif bagi Pemerintah Desa Grajagan maupun warga desa setempat baik secara langsung maupun secara tidak langsung. Dampak positif secara langsung dari implementasi kegiatan ini adalah bertambahnya koleksi buku, bertambanya perabot, dan meningkatnya pengetahuan petugas perpustakaan dalam mengelola Perpustakaan Desa Grajagan. Dengan adanya dampak langsung tersebut, diharapkan akan timbul dampak tidak langsung yaitu meningkatnya kunjungan warga setempat ke perpustakaan desa dan meningkatnya minat baca sehingga pengetahuan warga desa akan bertambah.

\section{Kesimpulan}

Berdasarkan hasil kegiatan pengabdian kepada masyakat yang telah dilakukan, dapat dinyatakan bahwa koleksi buku di Perpustakaan Desa Grajagan bertambah sebanyak 88 judul buku, ruang Perpustakaan Desa Grajagan menjadi lebih nyaman dengan koleksi buku yang lebih lengkap dan tertata baik, serta bertambahnya perabot-perabot seperti meja, kursi, jam dinding, dan sejumlah perabot lainnya, dan petugas Perpustakaan Desa Grajagan bertambah pengetahuannya dalam hal pengelolaan 
GANDRUNG: Jurnal Pengabdian Kepada Masyarakat ISSN: 2721-6136 (Online)

perpustakaan.Untuk lebih meningkatkan peran dan fungsi Perpustakaan Desa Grajagan diperlukan upaya promosi atau pengenalan tentang koleksi buku dan fasilitas yang dimiliki oleh perpustakaan tersebut. Promosi perpustakaan dapat dilakukan dengan sasaran siswa-siswi pada beberapa sekolah di wilayah Desa Grajagan, ibu-ibu PKK, karangtaruna, dan warga desa lainnya. Adanya promosi perpustakaan tersebut diharapkan dapat memberi informasi kepada masyarakat tentang sumber belajar yang ada di desanya sehingga masyarakat lebih tertarik untuk menggunakan perpustakaan dan meningkat minat bacanya.

\section{Ucapan Terima Kasih}

Terima kasih kepada : (1) Fakultas Teknik Universitas Brawijaya yang telah membiayai kegiatan Pengabdian kepada Masyarakat ini melalui Sumber Dana PNBP berdasarkan Surat Perjanjian Nomor: 30/UN10.F07/PM/2020 tanggal 13 April 2020, (2) Kepala Desa Grajagan beserta para aparat desa atas kerjasama aktif sebagai mitradalam pelaksanaan kegiatan ini.

\section{Daftar Referensi}

Badan Arsip dan Perpustakaan Pemerintah Provinsi Jawa Tengah. (2009). Pedoman Penyelenggaran Perpustakaan Sekolah Menengah Atas. Semarang: Badan Arsip dan Perpustakaan Pemerintah Provinsi Jawa Tengah. https://perpus.jatengprov.go.id/pedoman-teknis/perpussma/files/res/mobile/?C=S;O=A

BPS Kabupaten Banyuwangi. (2018). Kecamatan Purwoharjo Dalam Angka 2018. Banyuwangi: BPS Kabupaten Banyuwangi.

BPS Kabupaten Banyuwangi. (2019). Kecamatan Purwoharjo Dalam Angka 2019. Banyuwangi: BPS Kabupaten Banyuwangi.

Darmono. (2017). Pengembangan Perpustakaan Sekolah sebagai Sumber Belajar. Jurnal Perpustakaan Sekolah, 1(1), 1-10. http://digilib.um.ac.id/images/gbjps/art01dar.pdf

Miswan. (2003). Klasifikasi dan Katalogisasi: Sebuah Pengantar. "Workshop Perpustakaan dan Kearsipan". STAIN Purwokerto. http://eprints.rclis.org/10296/1/Masjid_library-training.pdf

Restanti, A. S., Astuti, E. Y., Munjiati, Nurwijayanti, U., \& Widianingtias, S. (2017). Pengelolaan Perpustakaan di Sekolah Dasar Negeri 02 Karangwangkal Purwokerto. Prosiding Seminar Nasional dan Call for Papers "Pengembangan Sumber Daya Perdesaan dan Kearifan Lokal Berkelanjutan VII". http://jurnal.lppm.unsoed.ac.id/ojs/index.php/Prosiding/article/viewFile/420/344

Riduwan. (2010). Skala Pengukuran Variabel-variabel Penelitian. Cetakan ketujuh. Bandung: Alfabeta. 
GANDRUNG: Jurnal Pengabdian Kepada Masyarakat ISSN: 2721-6136 (Online)

Rodiah, S., Budiono, A., \& Komariah, N. (2018). Penguatan Peran Perpustakaan Desa dalam Diseminasi Informasi Kesehatan Lingkungan. Dharmakarya: Jurnal Aplikasi Ipteks untuk Masyarakat, 7(3), 197-202. https://doi.org/10.24198/dharmakarya.v6i3.19350

Rotmianto, M. (2015). Mencermati Nomor-Nomor Opsional (Optional Number) dalam Sistem Klasifikasi Persepuluhan Dewey Edisi 23 (DDC Edition 23). Record and Library Journal, 1(1), 48-58. https://doi.org/10.20473/rlj.V1-I1.2015.48-58

Sriagustini. (2016). Strategi Pengembangan Perpustakaan Umum Pemerintah Kabupaten Tulungagung. Jurnal Ekonomi Bisnis, 21(2), 147-162. http://journal.um.ac.id/index.php/ekobis/article/view/7428/3379

Undang-Undang Republik Indonesia No. 43 tahun 2007 tentang Perpustakaan.

Widiyastuti. (2017). Desain Perpustakaan Ideal di Era Modern. JIPI (Jurnal IImu Perpustakaan dan Informasi), 2(2), 200-211. https://doi.org/10.30829/jipi.v2i2.1256 